\title{
Diversity and characterization of entomopathogenic fungi from rhizosphere of maize plants as potential biological control agents
}

\author{
NOVRI NELLY", MY SYAHRAWATI, HASMIANDY HAMID, TRIMURTI HABAZAR, DWI NASRI GUSNIA \\ Department Plant Protection, Faculty of Agriculture, Universitas Andalas. Jl. Universitas Andalas, Kampus Unand Limau Manis Padang 25163, West \\ Sumatera, Indonesia. Tel.: +62-751-72701 Fax.+62-751-72702. `email novrinelly@agr.unand.ac.id, novrinelly@yahoo.com
}

Manuscript received: 9 April 2019. Revision accepted: 28 April 2019.

\begin{abstract}
Nelly N, Syahrawati MY, Hamid H, Habazar T, Gusnia DN. 2019. Diversity and characterization of entomopathogenic fungi from rhizosphere of maize plants as potential biological control agents. Biodiversitas 20: 1435-1441. The diversity and characters of entomopathogenic fungi in soil are influenced by cultivation techniques. This study aims at determining the characters and pathogenicity of entomopathogenic fungi in maize plant. Materials were extracted from maize plant rhizosphere at different planting system (monoculture, polyculture, and monoculture of corn on formerly oil palm plantation or replanting) in Nagari Koto Baru, Luhak Nan Duo Subdistrict, West Pasaman District, and West Sumatra Province. Insect bait and series dilution were used to carry out the isolation, while Tenebrio molitor larvae were used for the pathogenicity test. Parameters observed include macroscopic and microscopic characteristics, and pathogenicity of entomopathogenic fungi. The result shows that there are three types of entomopathogenic fungi with various features. After identification, it was known that Aspergillus and Metarizium were obtained from mono, polyculture and by replanting crops, while Beauveria was found from the rhizosphere of corn grown in polyculture with pathogenicity identified as one of the high causes of death to larvae T. molitor with LT50 ranging from 48.03-48.48 hours.
\end{abstract}

Keywords: Characterisation, diversity, entomopathogenic fungi, rhizosphere

\section{INTRODUCTION}

Pests and diseases affect the productivity of corn plants. And the main pests attack corn are corn borer (Helicoverpa armigera), armyworm (Spodoptera litura) and grasshopper (Valanga nigricornis) (Adnan 2011). Others such as S. pacificus, are found in field and spread in several regions in West Sumatra, (Nelly et al. 2017). The intensity of damages developed on maize is usually between $26-50 \%$ and weighs from $51-75 \%$, owing to attacks from armyworms, grasshoppers and cob borer. To overcome these damages, adequate control efforts are required (Fattah and Hamka 2008).

Generally, corn pest is controlled by using resistant varieties, technical culture or synthetic insecticides. However, this has not been effective because these pests have short life cycles and high adaptability (Bakhri 2007 and Patty 2012). Furthermore, the continuous use of synthetic insecticides can have some negative effects on the environment. It could lead to resistance, resurgence, residue, and death (Sofia 2001). To overcome this problem, other environmentally friendly biological control techniques should be utilized (Baliadi et al. 2008). Biological control for pests consists of predators, parasitoid and entomopathogen (Habazar and Yaherwandi 2006).

Entomopathogenic is a microorganism capable of treating diseases in insects. It comprises of fungi, bacteria, viruses, nematodes, and protozoa (Habazar and Yaherwandi 2006). Several species reported to be effective in controlling insect pests are Beauveria bassiana, Metarhizium anisopliae, Nomuraea rileyi, Paecilomyces fumosoroseus, Aspergillus parasiticus and Verticillium lecanii (Prayogo 2006). B. bassiana and M. anisopliae effectively control green ladybugs (Nezara viridula) $96.40 \%$ (Suprayogi et al. 2015). N. rileyi effectively controls $H$. armigera $36-85.56 \%$ (Indrayani 2013). The $P$. fumosoroseus Ultra Low Volume (ULV) formula with an additional $15 \%$ corn oil effectively controls Bemisia tabaci (Kamalin 2011). A. parasiticus is effective in controlling $S$. litura 65\% (Prayogo 2006). V. lecanii with conidia $108 / \mathrm{ml}$ density effectively control green leafhopper (Nephotettix virescens) 50\% (Ladja 2009).

Entomopathogenic source comes from plants such as endophytic fungi, infected insects, and from soil or rhizosphere. Entomopathogenic fungi are often found around the rhizosphere of plants in soil, because its availability is higher (Carlile et al. 2001). Beauveria, Metarhizium, Nomuraea, Paecilomyces, Fusarium, and Aschersonia are found in cabbage and vegetable plants (Nuraida and Hasyim 2009) Metarhizium (Trizellia et al. 2016). Metarhizium sp., Beauveria sp., Penicillium sp. and Aspergillus sp. are found in rhizosphere of corn in Lampung region (Semenguk 2016).

The presence of entomopathogenic fungi in soil is influenced by several factors, such as the content of soil water, organic matter and compounds (Carlile et al. 2001). Furthermore, the diversity of entomopathogenic fungi is also influenced by the sea level's cultivation and altitude (Trizelia et al. 2015) as well as the types of protective plants affected by microorganisms (Hamdani 2009). Type of planting pattern in the field that is thought to affect the presence of fungi, namely polyculture, monoculture and 
replanting. Polyculture is a form of agriculture in which more than one species is grown at the same time and place in imitation of the diversity of natural ecosystems (Chrispeels and Sadava 1994). Monoculture, in which only members of one plant species are cultivated and replanting is replanting plants that do not produce. The diversity of entomopathogenic fungi in polyculture cropping is higher in the highlands. It consists of 9 isolates, while the monoculture cropping pattern consists of 7 (Trizelia et al. 2015).

Entomopathogenic indigenous fungi are said to be more effective for pest control. According to Khasanah (2008), B. bassiana local strain concentration of $0.6 \mathrm{mg} / 1$ water in sweet corn plants is effectively used in controlling corn borer. It is often planted mono and polyculture or on oil palm plantations being replanted. Information about indigenous entomopathogenic fungi related to these cultivation techniques has not been widely reported. As a result, this research was carried out with the aim of obtaining entomopathogenic fungi from rhizosphere in monoculture, polyculture, and oil palm replanting.

\section{MATERIALS AND METHODS}

\section{Study area}

This research was conducted and implemented from November 2017 to May 2018 at the Biological Control laboratory, Faculty of Agriculture, Andalas University, Padang, West Sumatra, Indonesia with sampling carried out at Jorong Ophir and Giri Maju, Nagari Koto Baru, Luhak Nan Duo Sub-district, and Pasaman Barat District, West Sumatra, Indonesia.

\section{Material and tools}

Materials and the tools used were maize plant rhizosphere, medium Sabaoraud Dextrose Agar with Yeast Extract (SDAY), Potato Dextrose Agar (PDA), hemocytometer Improved Neubauer nesco (vol. 0,0002 $\left.\mathrm{mm}^{2}\right)$, etc.

\section{Sampling of rhizosphere soil from maize plants and isolation of entomopathogen fungi}

Three samples soil were taken and extracted from monoculture, polyculture, and palm replanting sites. The soil is taken by digging around the rhizosphere with a depth of $10-20 \mathrm{~cm}$ and a stem distance of $3 \mathrm{~cm}$. About $1 \mathrm{~kg}$ of each plant is put into a plastic bag and taken to the laboratory. Rhizosphere soil is also extracted from the root, by removing the corn plants. The fungus isolation was carried out by insect bait and serial dilution method.

\section{Insect bait}

According to Trizelia et al. (2015), the insect bait method is achieved using T. molitor larvae. These are maintained in plastic boxes measuring $25 \mathrm{~cm} \times 15 \mathrm{~cm}$ and fed $100 \mathrm{~g}$ of larvae daily. Soil around the rhizosphere from 5 points is combined and sieved with a 60 mesh. After sieving, the sample is divided into 5 and placed in a plastic box measuring $10 \times 15 \mathrm{~cm}$. The soil is moistened with 100 $\mathrm{ml}$ of distilled water and $10 \mathrm{~T}$. molitor larvae, with $2 \mathrm{~cm}$ of its length put into skin. T. molitor larvae are covered with a layer of soil and observed every day until they die. The fungus attacked by fungi is cultured using the moist chamber method. Larvae is soaked with aquadest, and $70 \%$ Alcohol at an interval of one minute respectively to sterile the surface. The sterilized larvae are inserted into a petri dish containing moist tissue and incubated until the fungus grows at room temperature. Entomopathogenic fungi that grow are cultured on SDAY media, until ascertained pure using a microscope (Watanabe (2002); Bannett and Hunter (1972).

\section{Serial dilution}

The serial dilution technique (series dilution) refers to Trizelia et al. (2015) techniques which has been modified as follows: $10 \mathrm{~g}$ of plant roots are taken and homogenized in $100 \mathrm{ml}$ of sterile distilled water for 2 minutes, $1 \mathrm{ml}$ of suspension is put into the test tube containing $9 \mathrm{ml}$ distilled water and homogenized for 2 minutes. $1 \mathrm{ml}$ of the suspended dilution was transferred into a container containing PDA and incubated at room temperature until the growing mushroom filled the Petri dish. PDA mediums are observed every day. Each colony that grows and shows different fungal characteristics is re-isolated in the cuprion until pure culture is obtained. Pure fungus culture was tested by entering $10 \mathrm{~T}$. molitor larvae that replaced the skin, and observed for 7 days. Fungi that can infect $T$. molitor larvae are re-cultured on SDAY media.

\section{Identification of entomopathogenic fungi}

The isolates of the entomopathogenic fungi were identified as macroscopically and microscopically. The macroscopic figure was observed in color and shape with the microscopic fungus identified using a microscope by observing the conidiophores branching and conidia. The identification results were compared with Watanabe (2002) and Bannett (1972).

\section{Pathogenicity test of entomopathogenic fungi on larva Tenebrio molitor}

Pathogenicity is the fungus capable of infecting $T$. molitor larvae was tested. The fungus is isolating every 10 $\mathrm{ml}$ for 24 hours. Larvae fed and fungus was transferred into a $5 \mathrm{~cm}$ plastic tube. Larvae $T$. molitor were observed every 24 hours for 10 days.

\section{Identification of entomopathogenic fungi}

The fungus was identified at the genus level by observing macroscopic (color, colony shape, growth rate) and microscopic (conidiophores branching, conidia form, conidia density, and sprout power). Observation methods are as follows:

Fungi colony growth rate: The entomopathogenic fungus growth was measured by the size of the colony using millimeter paper on the second day until the fungusfilled the Petri dish.

Conidia density of entomopathogenic Fungi: Conidia density was calculated using the dilution method. The conidia of the fungus were suspended with $10 \mathrm{ml}$ of 
aquadest in Petri dish containing pure culture. This is known as base suspension. Next, it is diluted to $10^{-3}$ and 1 $\mathrm{ml}$ of the suspended distillate taken with a micropipette and placed on a hemocytometer and covered with glass. The hemocytometer was placed under a microscope and number of conidia counted. Observations were carried out with low magnification. To calculate the density of conidia/ml, the following formula is used:

Conidia density $=\frac{\text { The total number of conidia in the box observed }}{\text { Number of boxes observed }} 4 \times 10^{6} \times \mathrm{P}$

Where:

$\mathrm{P}=$ large dilution

Conidial sprout: The fungus is suspended with $10 \mathrm{ml}$ of aquadest and homogenized with vortex. A drop is suspended on a glass object covered and placed in a Petridish containing moist filter paper. The suspension was incubated for 18 hours at room temperature after which conidia were germinated using a $40 \mathrm{x}$ magnification microscope. The percentage of sprouts was calculated from 50 conidia which are said to germinate when the length of the tube exceeds its diameter.

\section{Pathogenicity of entomopathogenic fungi}

Incubation period: The incubation period was observed to determine the time needed by the fungus to cause symptoms in T. molitor larvae.

Mortality of Tenebrio molitor larvae per day: Each day, the mortality rate of $T$. molitor larvae was calculated from the first until the $10^{\text {th }}$ day of observation.

Total mortality of Tenebrio molitor larvae: Larval mortality rate was calculated based on the number of $\mathrm{T}$. molitor larvae that died 10 days after treatment. Calculations are carried out every 24-hour interval using the formula:

\section{$\mathrm{M}=\mathrm{n} / \mathrm{M} \mathrm{X} 100 \%$}

note:

M = Larval mortality

$\mathrm{n}=$ Number of dead larvae

$\mathrm{N}=$ Number of larvae observed

Lethal Time (LT): The LT is calculated from the percentage of test larvae deaths. LT50 is the time point at which mortality of inoculated hosts (larvae) is 50\%. To determine the value of LT50 used probit analysis.

Entomopathogenic fungus sporulation in $T$. molitor: Fungus sporulation was observed by calculating $\mathrm{T}$. molitor larvae infected with entomopathogenic from the first till the $7^{\text {th }}$ day after treatment with a 24-hour interval using the formula:

$$
\mathrm{S}=\frac{n}{N} \times 100 \%
$$

Where:

$\mathrm{S}=$ Sporulation of entomopathogenic fungi

$\mathrm{n}=$ Number of sporulating larvae

$\mathrm{N}=$ Number of larvae observed

\section{RESULTS AND DISCUSSION}

\section{Identification of entomopathogenic isolates}

Three entomopathogenic fungi with different features were found in the isolates with the results compared to Watanabe (2002) and Bannett and Hunter (1972). The fungi obtained were Aspergillus, Metarhizium, and Beauveria with the macroscopic and microscopic morphological observations shown in Table 1.

Amongst the three entomopathogenic fungi obtained, Aspergillus and Metarizium were found in monoculture, polyculture and replanting soils, while Beauveria was only found in polyculture fields. The observation of incubation period, growth rate, germination and conidial density of each fungus isolate can be seen in Table 2 .

From Table 2 it can be seen that incubation period, the growth rate, germination and conidial density of all isolates were not different based on the analysis of variance (ANOVA) ( $\mathrm{P}>0.05)$. The incubation period of all isolates is 3 days with symptoms arising a day after the larvae's death. Colony growth rates are also not too different ranging from 23-24 cm2. While the highest germination rate was Metarizium isolate which was $81 \%$, with conidia density of $18 \times 10^{7}$.

\section{Pathogenicity of entomopathogenic fungi}

The observation results of larval deaths due to entomopathogenic fungi can be seen after 24 hours. On the 5th and 7th day after death, sporulation was seen. $T$. molitor larvae attacked by entomopathogenic species of Aspergillus showed a yellowish color, Metarizium greenish while that of Beauveria was white (Figure 1).

Dead larvae infected with entomopathogenic fungi are characterized by dry, stiff and color changes. After a day visible hyphae are seen growing around the region. The number of hyphae that grows continues to grow in accordance with increasing time. In the end, the entire body of the larva will be enveloped by entomopathogenic fungal hyphae.

Table 2. Incubation period, growth rate, germination and conidia density of entomopathogenic fungi from corn rhizosphere

\begin{tabular}{lcccc}
\hline Isolate & $\begin{array}{c}\text { Incubation } \\
\text { period } \\
\text { (days) }\end{array}$ & $\begin{array}{c}\text { Growth } \\
\text { rate } \\
\left(\mathbf{c m}^{\mathbf{2}}\right)\end{array}$ & $\begin{array}{c}\text { Germination } \\
(\boldsymbol{\%})\end{array}$ & $\begin{array}{c}\text { Conidia } \\
\text { density }\end{array}$ \\
\hline Aspergillus & 3 & 23.32 & 64 & $3.6510^{7}$ \\
Metarizium & 3 & 24.65 & 81 & $1.810^{7}$ \\
Beauveria & 3 & 23.47 & 73 & $1.610^{7}$ \\
\hline
\end{tabular}


Table 1. Macroscopic and microscopic entomopathogenic fungi from corn rhizosphere

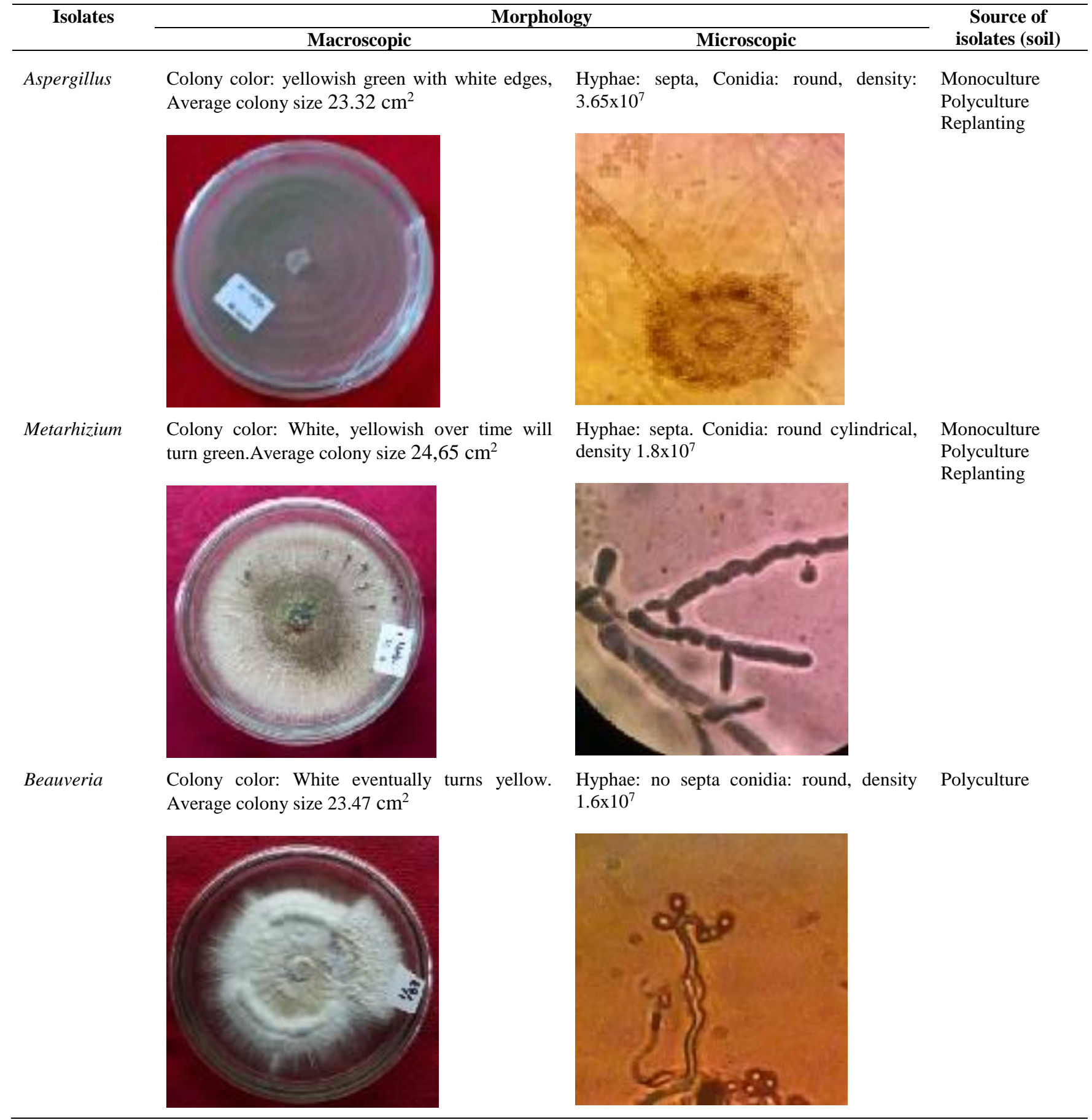

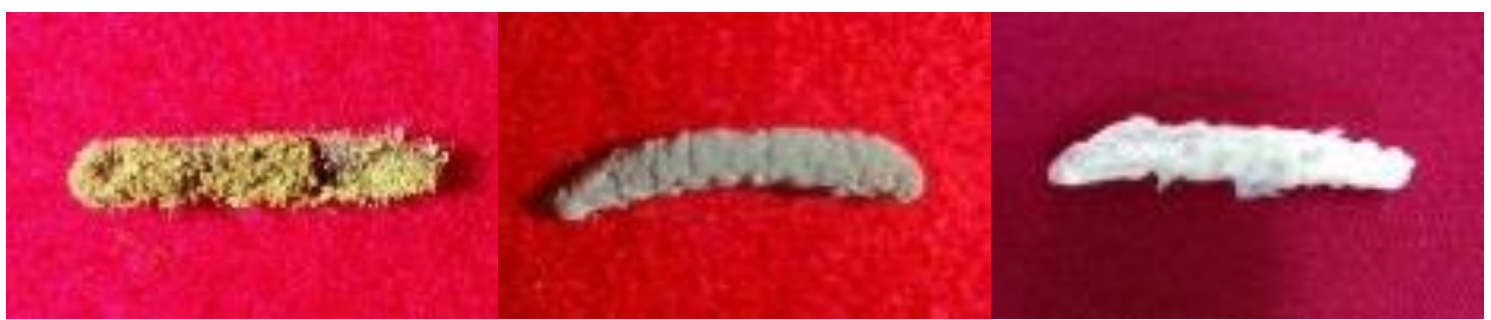

A

Figure 1. Larvae infected by Aspergillus sp. (A), Metarizium (B), and Beauveria (C) on the $5^{\text {th }}$ day after death 


\section{Mortality of Tenebrio molitor larvae}

The average mortality rate of larvae by Metarizium and Beauveria was same with a $100 \%$ rate after treatment on day 3. In contrast to the test larvae applied with fungi, Aspergillus sp. had a mortality value of $18.33 \%$ for monoculture and polyculture, while isolates from replanting plants were $12.67 \%$. The LT50 Metarizium fungus is isolated from maize plantations with cultivation or polyculture, replanting, and monoculture for 49.032 hours, 48.912 hours and 48.48 hours respectively. LT50 Beauveria fungus had duration of 49.368 hours while Fungus Aspergillus had a polyculture, monoculture, and replanting of 55.27 days, 37.20 days and 30.23 days (Table 3). It is estimated that Aspergillus isolates are entomopathogenic, but are not effectively used as control agents.

If the observed larval mortality rate is determined with different entomopathogenic fungi, variety of developments will be recognized. Similarly, the environmental conditions of the plant originating from different isolates, such as polyculture, monoculture, and replanting of oil palm plants, resulted in differences. Aspergillus fungi with different isolates (mono, polyculture and replanting) were then applied to Tenebrio, showing an increase in mortality starting after day 2 (Figure 2).

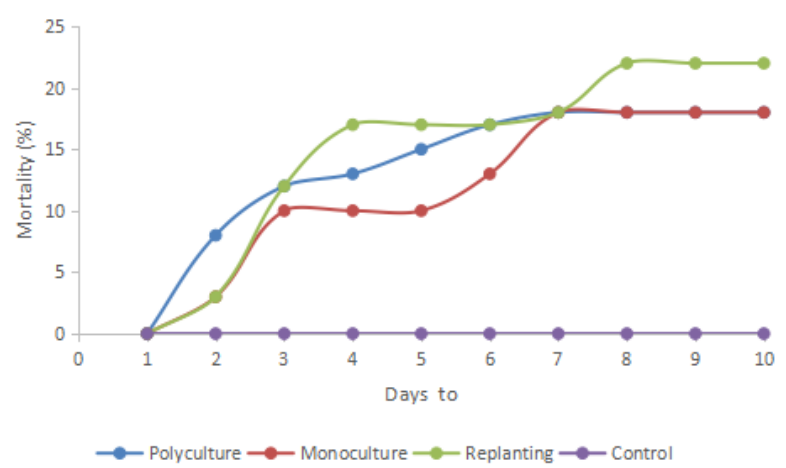

Figure 2. Mortality of Tenebrio molitor larvae per day after treatment of Aspergillus sp.

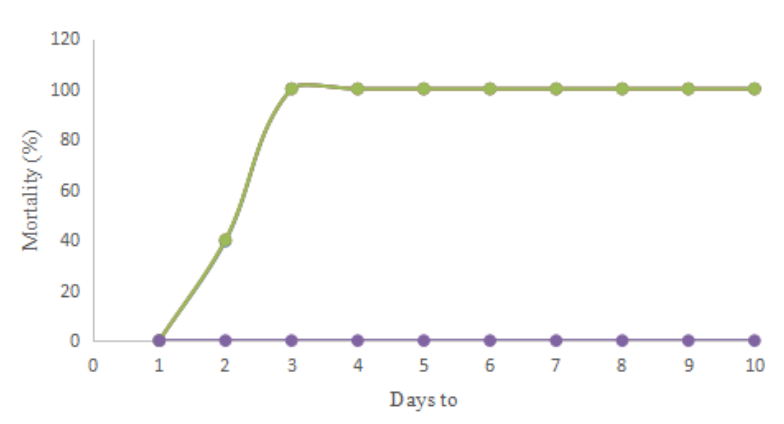

Figure 3. Mortality of Tenebrio molitor larvae per day after treatment with Metarizium
Larvae death due to Aspergillus sp. infection, commenced on the second day after treatment with different isolates from the plant origin. Isolates from monoculture land mortality were $3 \%$, while that of day 3 was $10 \%$. The number of new larvae deaths increased on the 6 th and $7^{\text {th }}$ day to $13 \%$ and $18 \%$ respectively. This percentage was steady until the 10th day of observation. Similarly, isolates from polyculture and replanting fields increased until the 10th day.

The result was obtained with the application of Metarizium and Beauveria fungi. Death occurs after the second day of application, and increased until the third to 10th day with $100 \%$ mortality rate (Figures 3 and 4).

Table 3. Mortality rates and LT50 Tenebrio molitor larvae after treatment of entomopathogenic fungi

\begin{tabular}{llcc}
\hline \multicolumn{1}{c}{ Isolate } & \multicolumn{1}{c}{ Land } & $\begin{array}{c}\text { Mortality } \\
(\boldsymbol{\%})\end{array}$ & LT50 (days) \\
\hline Aspergillus & Polyculture & 18.33 & 55.27 \\
& Monoculture & 18.33 & 37.20 \\
& Replanting & 21.67 & 30.23 \\
Metarhizium & Polyculture & 100 & 2.04 \\
& Monoculture & 100 & 2.02 \\
& Replanting & 100 & 2.04 \\
Beuveria & Polyculture & 100 & 2.06 \\
\hline
\end{tabular}

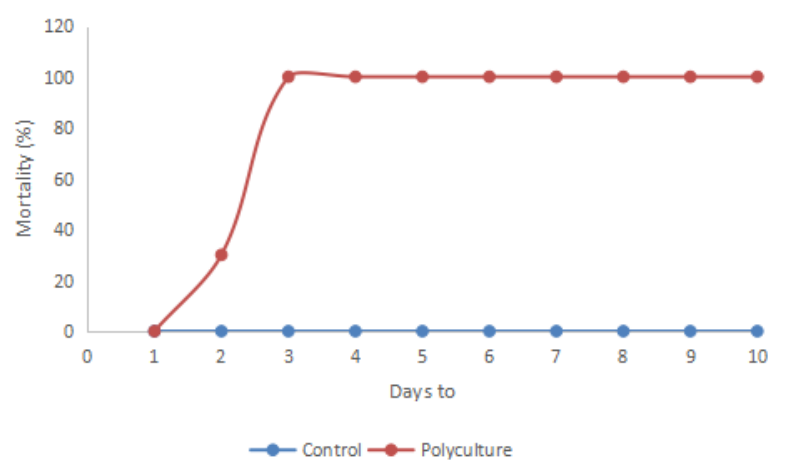

Figure 4. Mortality of Tenebrio molitor larvae per day after treatment with Beauveria

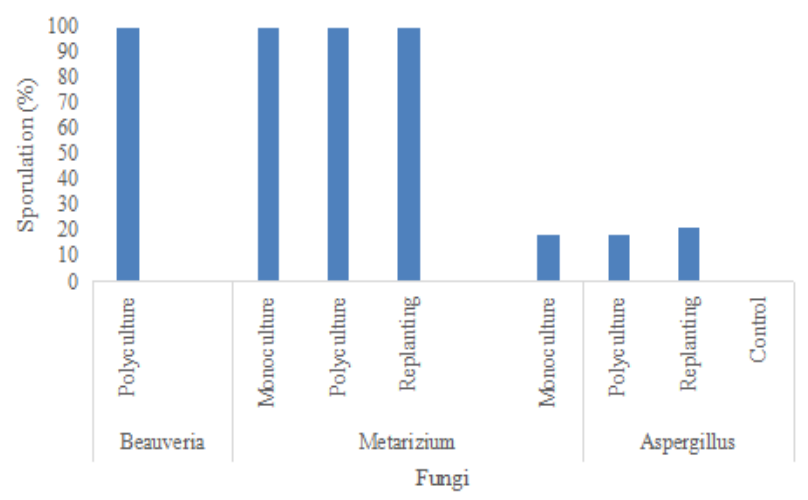

Figure 5. Average sporulation of entomopathogenic fungi in Tenebrio molitor larvae after treatment with isolate from different fields 
Larvae death caused by Metarizium fungi occurred on the second day. Mortality T. molitor larvae on the second day by isolates different fields; $42 \%$ monoculture, $35 \%$ polyculture, and $37 \%$ replanting. On the third day, it increased to $100 \%$. That of Beauveria occurred on the second day, by $30 \%$ and the third day it increased to $100 \%$ (Figure 4).

\section{Entomopathogenic fungus sporulation in $T$. molitor}

The highest sporulation rate of entomopathogenic fungi by Metarizium and Beauveria is $100 \%$ and the lowest Aspergillus is $18.33-21.67 \%$ (Figure 5).

The average sporulation of Metarizium and Beauveria fungi was the same, (100\%) and different from the fungus Aspergillus. which has a sporulation value of only 18.33$21.67 \%$. So the effectiveness of Aspergillus is much lower than Metarizium and Beauveria. However, when compared with controls, entomopathogenic fungi differ so much that the entomopathogenic fungi obtained are able to kill $T$. molitor larvae.

\section{Discussion}

Three entomopathogenic isolates were found in the rhizosphere of maize plants taken from different cultivated fields, namely mono and polyculture as well as on replanted palm oil fields. Entomopathogenic fungi can be found in the rhizosphere, soil, plants or in infected insects (Wilyus and Schue 2015). Its presence is influenced by several factors such as site height, protective plant species and cultivation techniques (Hamdani 2009; Trizelia et al 2015). One cultural method that influences the diversity of entomopathogenic fungi is the planting system, such as monoculture and polyculture. Corn in some areas is also planted on replanted land or oil palm.

The advantage of polyculture planting systems is the diversity of living things and high organic matter. In addition, it affects soil temperature, with high moisture because its surface is covered by a leaf canopy (Nurindah 2006). The content of organic matter and soil moisture is directly proportional to the population of microorganisms. The higher organic content of matter causes the greater diversity (Wicaksono et al. 2015). Carlile et al. (2001) reported that the diversity of entomopathogenic fungi was influenced by organic matter, soil water content, temperature, and soil microorganism population. This is directly proportional to the results of this study which obtained data on the diversity of entomopathogenic fungi in polyculture higher than monoculture and replanting. Monoculture and replanting, comprises of 2 types of entomopathogenic fungi, Aspergillus and Metarizium while polycultural land has 3 types of entomopathogenic fungi, namely Aspergillus, Metarizium and Beauveria. The low diversity of entomopathogenic fungi on monoculture land is caused by the diversity of vegetation and low organic matter, while on replanting land it is as a result of the use of herbicides. Emalinda et al. (2003) reported that the use of herbicides on the soil affects the population of microorganisms in the soil, improper use will reduce the population of microorganisms because the active ingredients contained can kill these organisms, thereby, affecting plant growth.

The effectiveness of entomopathogenic fungi is known from the mortality of test larvae. The higher the mortality, the more effective the fungus is used for control. The sporulation determines whether the larvae die due to the test fungus or not. From this study, the value of mortality and sporulation values were high by the Metarizium and Beauveria fungus, i.e. $100 \%$ while the Aspergillus has a mortality value of $18.33 \%$ for isolates from monoculture and polyculture fields and $12.67 \%$ replanting with sporulation values ranging from $10-40 \%$. This result is the same as the value of LT50 obtained with pollutant, replanting, and monoculture extracted in 2.043, 2.038 and 2.02 days. LT50 Beauveria is 2.057. LT50 Aspergillus is comprising of polyculture 55.27 days, monoculture 37.20 days and replanting 30.23 days. Aspergillus isolates from any field are not effective, because of the longtime lethal. Whereas Beauveria and Metahrizium isolates have a short value of LT50.

Differences in mortality values, sporulation values, and LT50 were obtained from Metarizium and Beauveria fungi with Aspergillus. It is related to the effectiveness of entomopathogenic fungus. According to the results reported by Erlina (2016), the value of LT50 is used by $B$. bassiana fungus to control Etiella zinckenella faster than the treatment of fungi Aspergilus sp. in 7.10 days while is in Aspergillus sp. 18.30 days. This is similar to the results of this study which states that the ability of Aspergillus fungus isolated to determine the cause of death was only tested at $18-21 \%$. It can be said that this fungus is less effective compared to the Metarizium and Beauveria fungi.

Based on the results and discussion, three types of entomopathogenic fungi with different characters and fields were analyzed. After being identified, Aspergillus and Metarizium from monoculture, polyculture and replanting land were obtained. While, Beauveria was found only in polyculture. The pathogenicity of Metarhizium and Beauveria is capable of causing deaths of up to $100 \%$ of larvae of $T$. molitor with LT50 ranged from 48.03-48.48 hours.

\section{ACKNOWLEDGEMENTS}

We would like to express gratitude and appreciation to Rector of Universitas Andalas, Padang, Indonesia who funded this study with Research Professor Cluster No. 04/UN.16.17/PP.RGB2/LPPM/2018 behalf of corresponding author (Novri Nelly).

\section{REFERENCES}

Adnan AM. 2011. Manajemen musuh alami hama utama jagung. Prosiding Seminar Nasional serealia. Sulawesi Selatan. [Indonesian]

Baliadi Y, Tengkano W, Bedjo S, Subandi. 2008. Pedoman Penerapan Rekomendasi Pengendalian Hama Terpadu Tanaman Kedelai di Indonesia. Puslitbangtan-Balitkabi. J. Litbang 27 (4): 108. [Indonesian] 
Bakhri S. 2007. Budidaya Jagung dengan Konsep Pengelolaan Tanaman Terpadu (PTT). Balai Pengkaji Teknologi Pertanian (BPTP) Sulawesi Tengah. [Indonesian]

Barnet HL, Hunter BB. 1972. Illustrated Genera of Imperfect Fungi. 3th Edition. Burgess Publishing Comp. Minnesota.

Carlile MJ, Watkinson SC, Goodday GW. 2001. The Fungi $2^{\text {nd }}$. Academy Press, New York; London.

Chrispeels MJ, Sadava DE. 1994. Farming systems: Development, productivity, and sustainability. In: Jones, Bartlett, Boston MA (eds). Plants, genes, and agriculture.

Emalinda O, Prima WA, Agustian. 2003. Effect of glyphosate herbicide on growth and diversity of microorganisms in soil and soybean growth (Glicyne max. (L) Merr) on Ultisol. Stigma 11: 309-314.

Erlina LR 2016. Pathogenicity of some endophytic fungus isolates from peanuts on Etiella zinckenella pod borer trait (Lepidoptera: Pyralidae). Faculty of Agriculture, UNAND, Padang.

Fattah A, Hamka. 2011. Tingkat serangan hama penggerek tongkol, ulat grayak dan belalang pada jagung di Sulawesi Selatan. Balai Pengkaji Teknologi Pertanian Sulawesi Selatan dan Balai Proteksi Tanaman Pangan dan Hortikultura Provinsi Sulawesi Selatan. Seminar Nasional Seredia Hal. 382-387. [Indonesian]

Fikri EN, Liestiany E. 2013. The effects of tomato planting and kenikir on Meloidogyne spp. on tomato plants. UNLAM 20 (2): 66-68. [Indonesian]

Ginting S, Santono T, Harahap IS. 2013. Potentiality of how fungus isolate against Coptotermes curvignathus Holmgren and Schedorhinotermes javanicus Kemmer. J Agrotek Trop 2 (1): 1-5.

Habazar T, Yaherwandi. 2006. Pengendalian Hayati Hama dan Penyakit Tumbuhan. Andalas University Press, Padang. [Indonesian]

Hamdani 2009. Keanekaragaman jenis cendawan entomopatogen yang berada di dalam tanah pada rhizosfir kakao di Sumatera Barat. [Tesis]. UNAND, Padang. [Indonesian]

Indrayani I, Prabowo H, Mulyaningsih S. 2013. Patogenisitas dua isolat lokal jamur Nomuraea rileyi (Farlow) Samson terhadap Helicoverpa armigera Hubner (Lepidoptera: Noctuidae). J Littri 19 (1): 8-14 [Indonesian]

Kamalin IM. 2011. Efektivitas cendawan entomopatogen Paecilomyces fumosoroseus (wize) Brown dan Smith untuk mengendalikan kutu kebul (Bemicia tabaci genn.) dengan menggunakan formulasi ULV. [Skripsi]. Jember University, Jember. [Indonesian]

Khasanah N. 2008. Pengendalian hama penggerek tongkol jagung Helicoverpa armigera Hubner (Lepidoptera : Noctuidae) dengan
Beauveria bassiana stain lokal pada pertanaman jagung manis di Kabupaten Donggala. J Agroland. 15 (2): 106-111. [Indonesian]

Ladja FAT. Santoso T, Nurhayati E. 2011. Potensi cendawan entomopatogen Verticillium lecanii dan Beauveria bassiana dalam mengendalikan wereng hijau dan menekan intensitas penyakit tungro. IPB. Penelitian Pertanian Tanaman Pangan 30 (2): 114-120. [Indonesian]

Mathen PS, Syamsuddin. 2015. Increasing local corn productivity through improving cropping patterns in drylands in Central Maluku Regency. Proceedings of Cereal National Seminar, 2015. [Indonesian]

Nuraida, Hasyim A. 2009. Isolasi, identifikasi, dan karakterisasi jamur entomopatogen dari rizosfir pertanaman kubis. J Hort 19 (4): 419432. [Indonesian]

Nurindah. 2006. Management of agroecosystems in pest control. Tobacco and Fiber Crop Research Institute. 2 (5): 78-85.

Sofia D. 2001. Pengaruh pestisida dalam lingkungan pertanian. Universitas Sumatera Utara, Medan. [Indonesian]

Suprayogi, Marheni, Oemry S. 2015. Uji efektiitas jamur entomopatogen Beauveria bassiana dan Metarhizium anisopliae terhadap kepik hijau ( Nezara viridula L.) (Hemiptera; Pentatomidae) pada tanaman kedelai (Glycine max L) di rumah kasa. J Online Agroekoteknologi. 1 (3): 320-327. [Indonesian]

Trizelia, Winarto. 2016. Diversity of entomopathogenic endophytic fungi in cocoa plants (Theobroma cacao). Pros Sem Nas Masy Biodiv Indon 2 (2): 277-281. [Indonesian]

Trizelia, Armon N, Jailani H. 2015. Diversity of entomopathogenic fungi in the rizosphere of various vegetable plants. West Sumatra. Pros Sem Nas Masy Biodiv Indon 1 (5): 998-1004. [Indonesian]

Prayogo Y. 2006. Upaya mempertahankan keefektifan cendawan entonopatogen untuk mengandalikan hama tanaman. Jurnal Litbang Pertanian 25 (2): 47-54. [Indonesian]

Watanabe T. 2002. Pictorial Atlas of Soil and Seed Fungi: Morphologies of Cultured Fungi and Key to Species. 2nd ed. CRC Press, New York.

Wicaksono T, Sagiman S, Umran I. 2015. Study of soil microorganism activities in several land use methods in Pal IX Village, Sungai Kakap District, Kubu Raya Regency. Tanjungpura University, Pontianak. [Indonesian]

Wilyus, Schue S. 2015. Potency of entomopathogenic fungi in tropical rainforest transformation in Jambi Province. Prosiding Seminar Nasional Lahan Suboptimal 2015, Palembang, 8-9 Oktober 2015. [Indonesian] 